Int. J. Electrochem. Sci., 15 (2020) 12724 - 12739

International Journal of

ELECTROCHEMICAL

SCIENCE

$\underline{\text { www.electrochemsci.org }}$

\title{
Determination of Glucose using Flow Injection Analysis and Borate Selective Electrode
}

\author{
Duygu Uner-Bahar ${ }^{*}$, And Ibrahim Isildak ${ }^{2}$ \\ ${ }^{1}$ Istanbul Gelisim University, Vocational School of Health Services, Biomedical Device Technology \\ Department, Istanbul, Turkey, \\ ${ }^{2}$ Yildiz Technical University, Faculty of Chemical and Metallurgical Engineering, Bioengineering \\ Department, Istanbul, Turkey. \\ *E-mail: duygu.uner1@gmail.com
}

doi: $10.20964 / 2020.12 .15$

Received: 24 July 2020 / Accepted: 19 September 2020 / Published: 31 October 2020

This study focuses on the development of a flow injection analysis method that performs nonenzymatic glucose measurement. It is aimed to develop a more economical blood glucose monitoring system by measuring the instant blood glucose level indirectly with borate based ion selective electrode. A nonenzymatic electrode based on carbon nanotube-silver borate (CNT-SB) composite electrode was developed and integrated into a flow injection analysis system as a detector, and glucose measurement was performed. Potentiometric measurement was made with this detection chamber. Heights of potentiometric peaks obtained were used for the determination of the amount of glucose in blood samples. Repeated injections were tested by using a mini-sized separation column as stationary phase and successful results were obtained. In addition, boronic acid solution was used as a carrier solution in the system, and it is predicted to be more accessible and simple method than the present non-enzymatic methods as it has ability at neutral $\mathrm{pH}$ conditions. The developed glucose measurement system was simple, economic and fast.

Keywords: Borate Sensor, Diabetes Diagnosis, Economic Blood Glucose Measurement, Health quality, Sustainability.

\section{FULL TEXT}

(C) 2020 The Authors. Published by ESG (www.electrochemsci.org). This article is an open access article distributed under the terms and conditions of the Creative Commons Attribution license (http://creativecommons.org/licenses/by/4.0/). 